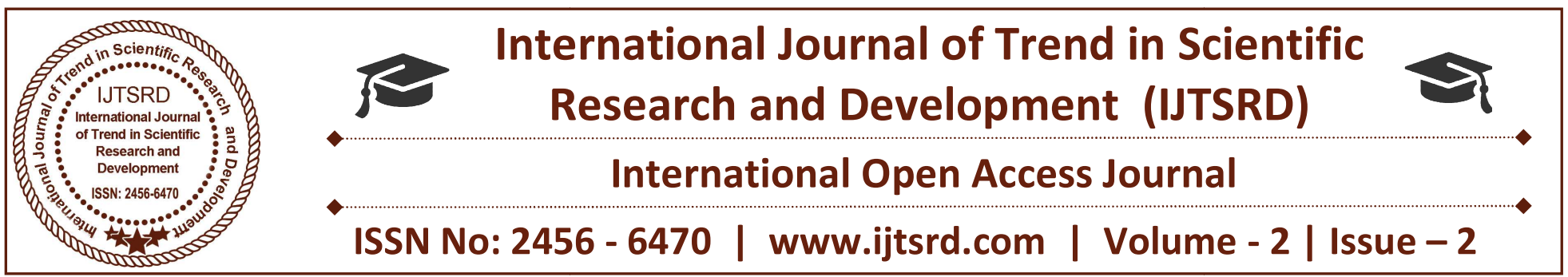

\title{
Keki N. Daruwalla's Poems: A Study of Post Independence Social Realism
}

\author{
Md Ataur Rahaman \\ Research Scholar, Department of English, \\ Tilka Majhi Bhagalpur University, Bhagalpur, Bihar, India
}

\begin{abstract}
Keki N.Daruwalla is one of the most substantial poets among the 'new' Indian English poets who radicalized Indian English poems both in theme and language. Pre Independence poets like Henry Louis Vivian Derozio, Michael Madhusudan Dutt , Toru Dutt ,Ramesh Chandra Dutt were mainly imitatorsthey imitated the cult of romanticism of the British romantic poets like William Wordsworth, Percy Bysshe Shelley, John Keats and Walter Scott. Apart from them there were poets like Sarojini Naidu, Rabindranath Tagore, Aurobindo Ghosh and Harindranath Chattopadhaya who were also romantic but their romanticism was fraught with spiritualism, nationalism, and mysticism.But the poets like Nissim Ezekiel, A.K. Ramanujan, Kamala Das and Keki N.Daruwalla were fed up with romantic idealism. They produced a body of protest literature in a satirical, cynical and ironical vein. Modernism in Indian English poetry made its inroads with them leading to the origin of 'New Poetry' in the Indian literary sky. They derived much from the modern poets like T.S. Eliot, Ezra Pound, W.B. Yeats, W.H. Auden, Wallace Stevens and Dylan Thomas. This paper is an attempt to probe the sensibilities of Daruwalla as a poet who has a profound concern for the post independence Indian social realism, of say, violence, corruption, hypocrisy etc. His poems bespeak of his social commitment as a poet and his broad humanism.
\end{abstract}

Keywords: modernism, social realism violence, corruption, hypocrisy

INTRODUCTION:

Indian English poetry has an age old heritage. It started its journey two hundred years before with the hands of Henry Louis Vivian Derozio. He along with Michael Madhusudan Dutt, Toru Dutt and Ramesh Chandra Dutt stands as the trend setter. In their poems there is the abundance of the cult of British romanticism. They imitated the art of the British romantic poets. Their arts were inspired by their inner voice But inthe post Independence period a coterie of new poets like Nissim Ezekiel, A.K.Ramanujan, Kamala Dad and Keki N. Daruwalla ushered in a total radicalization in the field of Indian English poetry both in terms of matter and manner of presentation. They were poets born out of experience of modernity. With these 'New' poets, social realism in Indian English poetry made its appearance which in England started with Charles Dickens after the Industrial Revolution. Such poets who were in terms of sentiment and articulation focused on the ugly realities of Post Independent India "a landscape of meaninglessness." In his introduction to "Indian Poetry in English ', Makarand Pranjape describes the literary scene and new aesthetic of Post Independence poets:

"Delayed by the idealism of nationalism and romanticism of Tagore and Naidu, the aesthetic found rapid acceptance in the disillusionment of the post Independence era. Instead of ushering in the promised golden age, independence India became a typical third world country, backward, corrupt, and hypocritical. 
The blood bath of the partition was the worst blow to those who professed non - violence.."(1)

Prior to this Indian English poetry was weak in social gesture. The World War II, partition, communal riots, the curses of casteism, misery, hunger, violence have been the chief causes for this shift in the literary world of Indian English poetry. These 'New poets ' drew much from the modern dominating poets like T.S.Eliot, Ezra Pound, W.B.Yeats, W.H.Auden and Wallace Stevens. Of them Keki N. Daruwalla has established himself as a triumphant voice who barely castigates the socio - political , cultural reality of contemporary India. His poems offer a study of social realism of the affairs of Post Independence India. In more than ten volumes Keki N. Daruwalla has expressed his personal response to the contradictions prevalent in Indian society. Like the Black American poets, his poems openly question the values, the prevailing social order and stridently denounce social and political injustice. Around Krishna Mehrotra, Jayanta Mahapatra, A.K.Ramanujan and Nissim Ezekiel are also social critics, but their approach lacks adequate social insight, basic boldness and sense of consistency. He is like an angry young man who fights bank and thinks forward against the ambient ugliness, corruption and oppressive forces operative in the society. Poetry, therefore, to him " has to be a social gesture, because on occasions I feel external reality bearing down on me from all sides with a pressure strong enough to tear the ear- drums." (2) In his 'Introduction 'to "The Poetry of Keki "N. Daruwalla " Ravi Nandan Sinha justifies what Daruwalla says :

"From Under Orion (1970) to Night River (2000) each book presents itself as an argument against the contention that Daruwalla, after all, is not socially committed as writers like Mulk Raj Anand." By virtue of being an I.P.S. officer Daruwalla enjoyed certain advantages. His profession gave him the exposure to life in the raw, created the basic boldness and sharpened his capacity for unfeigned social criticism. A selective study of his poetry would suffice to justify how Keki N. Daruwalla counts poetry as an essential part of the body of society,, an aesthetic of revival, a force for change, reorientation, awareness and future betterment.

A conscious artist and craftsman Keki N. Daruwalla is sparingly critical about the moral degradation and decadence in 20th century India. With a sharp sense of unsparing satire, he highlights contradictions, paradoxes, ironies, hypocrisies, ethnicities, violence and corruption, the stark realism of contemporary Indian life. A.N. Dwivedi in his "Forward to the Poetry of Keki N. Daruwalla : A Critical Study " says :

"As a poet, Daruwalla raises his powerful voice against the rampant corruption and moral degradation of modern man."(4) In the poem "Monologue in the Chambal Valley " Daruwalla castigates the hollowness of Indian civilization - the moral hepatitis it has been suffering from. The poem is a realistic presentation of the condition of women in India. In a matter of fact way the poet here gives a roll list of women from different regions as if they are different breeds of dogs or cattle to be displayed and then to be sold like commodity. The chief bandit confesses how the young girls from all over India are hijacked and sold to amoral, lecherous persons to gratify their lust:

"Do you recall how it was with the women when we started? Taunt breasted ones from the halls Brown ones from Bihar - soft and over ripe, Daughters of the desert, daughters of the forest tribes?

Where did we not sell them?"( )

The bandits and his informer are merely the tools of a large number of morally corrupt people in post independent 20th century India who exploit the abject poverty of the poor people. A keen social observer Daruwalla also shows how corruption has made inroads in the legal system. The bandits easily break law by bribing those who have the responsibility to maintain law and order. He is caught but set free by the police because he bribes the judge's stenographer so that he doesn't type the judgment on the given day. Daruwalla thus castigates the corrupt mentality of the people which safeguards and promotes immorality and decadence in Indian society.

Corruption is at the root of the mindset of the Indian people, Daruwalla is fully aware of it. In another poem named 'Graft' from ' Under Orion ' he shows social corruption as well. The act of adulteration is an invincible reality of today's India in all its spheres, and with money power nothing is impossible to be manipulated : 
"You may adulterate oils, make tablets out of chalks

Sell meat turning maggots, fish turning stale

Switch sawdust for jute, at the worst of times

The right buck at the right time tips the scales."

Religious hypocrisy also comes under his scrutiny. In corruption has taken an epidemic shape leaving the same poem named 'Graft' he shows the moral nothing uninfected: debauchery of the so called holy people. Actually

"To legalize a bastard you've to bribe the priest."

Even a non-Jew can be married to a Jew I, but for that Daruwalla unveils the hypocrisy of the avaricious the priest is to be bribed. In a very candid manner priests in Lodheswar temple:

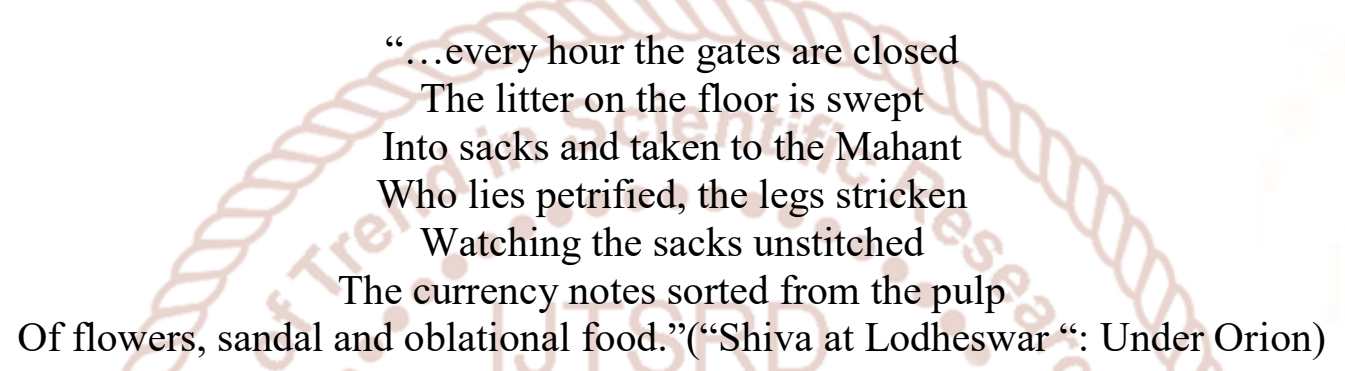

Daruwalla doesn't even spare political corruption. nthis is overtime he is getting."( 'Graft ' Under Orion The rotten social order owes its origin much to the ') rampant political corruption. The corrupt leaders have $n$ But Daruwalla leaves no stone unturned to tarnish the abdicated their only responsibility of serving the supposed god- figures who are in reality out and out nation. Seemingly they bear a clean image in the eyes of the society : corrupt, greedy, shrewd and hypocrite. With bitter satire the poet unfolds their masked face, of say, how the supposed nation servers fulfil the basic "he may not be given to lliquor, females, betting. He qualifications of a seasoned jail going criminal : is handsome, sauce and a family man: his wife thinks

"He is an old leader after all

Who has gone there to jail

Twice for home -rule

And once for sodomy."

( "Food and Words, Words and Food" : Apparition in April)

Such people are double - faced and they always befool the commoners :

"In the city house remains as it was, Cows and goats tethered in front,

People must still think that he was

Simple, one of them.

Only in bedroom air- conditioners hummed

And thick rugs covered it wall to wall.

And he started asking friends

What are those Swiss banks?

How the hell do they operate?'('Caries ') 
Their moral - self has become too shallow and, as such, it doesn't hammer their conscience to take bribe from the common people :

"Yet the hand grasps, nail gauge,

Somewhere a socket bleeds,

With extorted fruit the belly doesn't turn to fire'"( 'Graft ')

Such political leaders do not even hesitate to tax the Republic Day for political ends :

"Freeing robbers and rapists

On Republic Day

The amnesty adds

We'll review with sympathy

The cases of the following

Pumps, pederasts, poets.”('Village's: Under Orion)

Daruwalla doesn't even hesitate to criticize the hypocritical politicians. Such politicians capitalize sensitive situations by distorting facts and figures to win public acceptance. What is pitiable is to see the decent ones falling under the labyrinths of corruption :

\section{"If we had plague \\ Camus- style}

And doctors searched for the virus

There would be black market in rats"( 'Collage ':Under Orion )

Corruption is now an omnipresent entity and there is hardly any panacea for this social malady :

"Corruption is the chemistry of the flesh

No wonder the senses suppurate, passions outreach."( 'Mother ': Under Orion)

In such a cactus land Daruwalla feels no need to import the foreign brand of existentialism:

"Then why should I tread the Kafka beat

Or the Waste Land

When Mother, you are near at hand

One vast sprawling defeat."()

A sense of hopelessness and defeatism grips the poet's mind:

"Go to Auden and Sartre " they said

"For a vocabulary of defeat"

...For a landscape of meaninglessness

Go along with him

Out of absolute frustration and distortion of hope Daruwalla suggests a horrible solution to eradicate corruption. With rage and bitterness he makes a strange prayer to the Almighty:

"..Send them on another planet Lord

...For ten years let seed

Stay clear of the uterus

Let one generation be sterile.

Castrate the buggers if you like

No more men! No more women!

Save us Lord! Save us from ourselves.’('Bombay prayers' ) 
In this Daruwalla appeals to the readers as a Indian Jonathan Swift. Swift also in his ' A Modest Proposal ' proposes an exotic proposal to satirize the demoralized downtrodden Irish people. Daruwalla's satire is also deplete with a reformative zeal, of say, to usher in peace and harmony in the society.

Daruwalla doesn't even spare the common people, for they like to be duped by the corrupt politicians. It is they who hero-worship such leaders and promote them in their immoral acts:

\section{"they swarmed out like a nervous disorder \\ With his words in their mouths, \\ Misquoting, mispronouncing, misinterpreting; Confounding dialect with myth”('Apparition in April ‘)}

The politician for greater humanity Daruwalla has little trust in this imbecile social order. His is an ever worried - self, and it apprehends all pervasive violence in the shape of riots and rapes, caste and creed conflicts. In his visionary desert there is no hope for a better and regenerated tomorrow. In this he stands apart from T.S. Eliot. Eliot suggests an unfailing remedy in the mythical method of Prajapati
"Da,da,da,"i.e, self-control,giving and compassion for the modern wastelanders in 'The Waste Land'. Astoundingly what happens in today's India is awefully at par with Daruwalla's conviction. In the name of caste and creed, violence looms large everywhere and there is no hope for an oasis of freedom from violence. The poet, therefore, ruminates his violence - ridden vision :

"I can smell violence in the air

Like the lash of coming rain -

Mass hatreds drifting grey across the moon

It hovers brooding, poised like a cobra"

Daruwalla here uses a brilliant simile. He compares violence with a cobra. Community or communal violence is always venomous that would lead to killings. This violence between people always casts its spell unknown and unseen. Therefore, the poet says -

\section{"Death I am looking}

\section{For that bald bone - head of yours!” ('Ruminations': Under Orion)}

Intolerance, violence, riot in the name of what people are, what they believe and what they eat are the go of the day all over India. In 'Death By Burial' Daruwalla again shows how these differences rape humanism itself and lead to communal violence :

"They sewed them up in gunny-sacks alive

But here providence scurvy till now

$$
\text { Could still intervene }
$$

Half the village could be Hindu, half Muslim

Enough cause for a riot!

With half the village shouting death

"death by fire!"

And the other half

“death by burial!’'('Death by Burial ': Under Orion)

The social fabric of India and the discrimination among the people and the prejudices prevailing among them are well presented by the poet.

The still pervading mediaeval mentality doesn't end here. A feminist soul also dwells in him too, and he throws light on the plights of women in modern India.
They are still the victim of mediaeval patriarchal mentality. Theirs is a life of continual suffering. Familiar and marital discord prevail in their life either for dowry or for abject poverty. In the eyes of the society, a woman is a commercial product, a source of entertainment and an object for dominantion: 
"Women must be confined to the zenana

Like quail in a wicker basket "('The Keeper of the Dead')

Hunger, famine, deprivation are very common faces of India. What shocks Daruwalla is the mercenary motif of a section of people at such time. When the poorer section of the society suffers most during famine, a section of heartless people engage in trading the misery and affliction of the people. Hoarding, black-marketing, profiteering become the go of the day:

"No end of hoarding

Breaking open the lockers they find

A briefcase full of rice.'('Notes')

But Daruwalla is straightcut to call a spade a spade in this regard:

"I repeat", he screams, "no one

Obliges us by sending food!

They are duty-bound; the over-fed

Must feed the under-fed"

Daruwalla doesn't even set it aside to chide the superstitious blind beliefs still present in today's India. Standing on the 21 st century the poet in his poem 'The Epileptic ' shows how some people stand in queue to enjoy the supposed magical blessings of 'maulavi' to come round from illness. Daruwalla shows how under such circumstances a group of hypocrites takes advantage of the uneducated common people's ignorance and innocence.

\section{CONCLUSION:}

Most of the poems of Daruwalla thus justify his social responsibility as an artist. They objectify the stark realism of the ills of post independent India. What sets him apart from others is his satirical tone of poetic presentation. His anger and contempt are directed against the imbecile social order. Malthusian Prasad's comment deserves mention in this regard:

"As for social criticism he indisputably scores over other fellow poets who though have attempted social insight, basic boldness and above all a sense of consistency he is endowed with."(3)

\section{REFERENCES:}

1. Paranjape, Makarand. Indian Poetry In English (Madras: Macmillan. 1993) 19

2. Two Decades of Indian Poetry : 1960-1980, edited by Keki N. Daruwalla, Ghaziabad: Vikas Publishing House, 1980, P.21

3. Prasad, Madhusudan "Keki N. Daruwalla: Poet as Critic of His Age".Ed. Inamdar,F.A. New Delhi: Mittal Publications. 1991

4. Collected Poems 1970-2005, New Delhi: Penguin Books, 2006 